\title{
Spectral, magnetic and biological studies of 1,4-dibenzoyl-3- thiosemicarbazide complexes with some first row transition metal ions
}

\author{
NAND K SINGH*,1, SATY B SINGH ${ }^{1}$, ANURAAG SHRIVASTAV ${ }^{1}$ and \\ SUKH M SINGH ${ }^{2}$ \\ ${ }^{1}$ Department of Chemistry, and ${ }^{2}$ School of Biotechnology, Banaras Hindu \\ University, Varanasi 221005 , India \\ e-mail: nksingh@banaras.ernet.in
}

MS received 29 January 2001; revised 30 March 2001

\begin{abstract}
The ligand 1,4-dibenzoyl-3-thiosemicarbazide (DBtsc) forms complexes $[\mathrm{M}(\mathrm{DBtsc}-\mathrm{H})(\mathrm{SCN})] \quad[\mathrm{M}=\mathrm{Mn}(\mathrm{II}), \mathrm{Co}(\mathrm{II})$ or $\mathrm{Zn}(\mathrm{II})], \quad[\mathrm{M}(\mathrm{DB} t \mathrm{tsc}-$ $\left.\mathrm{H})(\mathrm{SCN})\left(\mathrm{H}_{2} \mathrm{O}\right)\right][\mathrm{M}=\mathrm{Ni}(\mathrm{II})$ or $\mathrm{Cu}(\mathrm{II})],[\mathrm{M}(\mathrm{DBtsc}-\mathrm{H}) \mathrm{Cl}][\mathrm{M}=\mathrm{Co}(\mathrm{II}), \mathrm{Ni}(\mathrm{II}), \mathrm{Cu}(\mathrm{II})$ or $\mathrm{Zn}(\mathrm{II})]$ and $\left[\mathrm{Mn}(\mathrm{DBtsc}) \mathrm{Cl}_{2}\right]$, which have been characterized by elemental analyses, magnetic susceptibility measurements, UV/Vis, IR, ${ }^{1} \mathrm{H}$ and ${ }^{13} \mathrm{C}$ NMR and FAB mass spectral data. Room temperature ESR spectra of the $\mathrm{Mn}$ (II) and $\mathrm{Cu}$ (II) complexes yield $\langle g\rangle$ values, characteristic of tetrahedral and square planar complexes respectively. DBtsc and its soluble complexes have been screened against several bacteria, fungi and tumour cell lines.
\end{abstract}

Keywords. 3d-Metal complexes; thiosemicarbazide; antitumour activity.

\section{Introduction}

Thiosemicarbazides and their complexes have been found to possess a wide variety of biological activities against bacteria ${ }^{1}$, fungi ${ }^{2}$ and certain type of tumours ${ }^{3}$. Some work has been done on the transition metal complexes of substituted thiosemicarbazides particularly the 1-aroyl-4-aryl derivatives ${ }^{4-8}$. 1,4-Dibenzoyl-3-thiosemicarbazide contains oxygen, sulphur and nitrogen as potential donor atoms and is liable to form deprotonated complexes by loss of hydrazinic proton(s) via enolisation/thioenolisation. In view of the absence of previous work on 1,4-diaroylthiosemicarbazides, we have prepared the complexes of 1,4-dibenzoyl-3-thiosemicarbazide (figure 1) with $3 d$-metal ions and studied their antifungal, antibacterial and in vitro antitumour activity.

\section{Experimental}

\subsection{Starting material}

All chemicals used were of analytical reagent or equivalent grade. Benzoyl isothiocyanate $^{9}$, benzoyl hydrazine ${ }^{10}$ and metal thiocyanates were prepared by literature methods.

*For correspondence 
<smiles>O=C(NNC(=S)NC(=O)c1ccccc1)c1ccccc1</smiles>

A

Figure 1. Structure of the ligand 1,4-dibenzoyl-3-thiosemicarbazide (DBtsc).

\subsection{1,4-Dibenzoyl-3-thiosemicarbazide (DBtsc)}

1,4-Dibenzoyl-3-thiosemicarbazide (DBtsc) ${ }^{11}$ was prepared by refluxing a suspension of benzoyl hydrazine $(1.36 \mathrm{~g}, 10 \mathrm{mmol})$ in dry benzene $\left(20 \mathrm{~cm}^{3}\right)$ with an equimolar amount of benzoyl isothiocyanate $(1.97 \mathrm{~g}, 10 \mathrm{mmol})$ for $4 \mathrm{~h}$. On cooling, the solid that separated was filtered, washed with benzene (to remove excess of benzoyl isothiocyanate) and water, dried and recrystallized from hot $\mathrm{EtOH}$, m.p. $172^{\circ} \mathrm{C}$ (Lit. $\left.172^{\circ} \mathrm{C}\right)$.

\subsection{Preparation of the complexes}

$[\mathrm{M}(\mathrm{DBtsc}-\mathrm{H})(\mathrm{SCN})](\mathrm{M}=\mathrm{Co}(\mathrm{II})$ or $\mathrm{Zn}(\mathrm{II})),\left[\mathrm{Ni}(\mathrm{DBtsc}-\mathrm{H})(\mathrm{SCN})\left(\mathrm{H}_{2} \mathrm{O}\right)\right],[\mathrm{M}(\mathrm{DBtsc}-$ $\mathrm{H}) \mathrm{Cl}](\mathrm{M}=\mathrm{Cu}(\mathrm{II}), \mathrm{Ni}(\mathrm{II})$ or $\mathrm{Zn}(\mathrm{II}))$ and $\left[\mathrm{Mn}(\mathrm{DBtsc}) \mathrm{Cl}_{2}\right.$ ] were prepared by refluxing the ethanolic solutions $\left(20 \mathrm{~cm}^{3}\right)$ of the respective metal (II) thiocyanate/chloride ( $3 \mathrm{mmol})$ and the ligand $(0.9 \mathrm{~g}, 3 \mathrm{mmol})$ for $\approx 1 \mathrm{~h}$. The complexes which precipitated on cooling were filtered, washed with cold EtOH and dried in vacuo. The [Mn(DBtsc$\mathrm{H})(\mathrm{SCN})]$ and $[\mathrm{Co}(\mathrm{DBtsc}-\mathrm{H}) \mathrm{Cl}]$ complexes were isolated by mixing and stirring the ethanolic solutions $\left(20 \mathrm{~cm}^{3}\right)$ of the respective metal (II) thiocyanate/chloride $(3 \mathrm{mmol})$ and the ligand $(0.9 \mathrm{~g}, 3 \mathrm{mmol})$, while $\left[\mathrm{Cu}(\mathrm{DBtsc}-\mathrm{H})(\mathrm{SCN})\left(\mathrm{H}_{2} \mathrm{O}\right)\right]$ was isolated by stirring together the DMF $\left(20 \mathrm{~cm}^{3}\right)$ solutions of $\mathrm{Cu}(\mathrm{SCN})_{2}(3 \mathrm{mmol})$ and the ligand $(0.9 \mathrm{~g}, 3 \mathrm{mmol})$, for $10-15 \mathrm{~h}$. The precipitated complexes were filtered, washed with the respective solvent and dried in vacuo.

\section{Physical measurements}

The complexes were analysed for their metal contents, following standard procedures ${ }^{12}$ after decomposition with a mixture of conc. $\mathrm{HNO}_{3}$ and $\mathrm{HCl}$, followed by conc. $\mathrm{H}_{2} \mathrm{SO}_{4}$. Sulphur and chloride were determined as $\mathrm{BaSO}_{4}$ and $\mathrm{AgCl}$, respectively. Carbon, hydrogen and nitrogen were estimated on a Perkin-Elmer 240C model microanalyser. Magnetic susceptibility measurements were made at room temperature on a CahnFaraday balance using $\mathrm{Hg}\left[\mathrm{Co}(\mathrm{NCS})_{4}\right]$ as calibrant. Electronic spectra were recorded on a Cary-2390 UV-Visible spectrophotometer in DMF solution. IR spectra were recorded in the $4000-400 \mathrm{~cm}^{-1}$ region as Nujol mulls on a Jasco FT/IR-5300 spectrophotometer. ${ }^{1} \mathrm{H}$ - and ${ }^{13} \mathrm{C}-\mathrm{NMR}$ spectra were recorded in DMSO- $d_{6}$ on a Jeol Fx-90QFT NMR spectrometer using TMS as internal reference. ESR spectra were recorded on an Xband spectrometer model EPR-112 using DPPH as a $\langle g\rangle$ marker. Molar conductance measurements were made using $10^{-3} \mathrm{M}$ solutions of the complexes in DMF employing a direct reading conductivity meter 303 provided with a cell, of cell constant 1.02. FAB 
mass spectra were obtained on a Jeol SX 1021 DA-6000 mass spectrometer using $m$ nitrobenzyl alcohol (NBA) as a matrix.

\section{Microbiol screening}

\subsection{Bactericidal screening}

Antibacterial activities of the ligand and the soluble complexes were evaluated by the disc diffusion technique ${ }^{13}$. Filter paper (Whatman No. 4) discs $(6 \mathrm{~mm}$ diameter) were soaked in a solution of the test compounds of $0.5 \mathrm{mg} \mathrm{cm}^{-3}$ concentration in DMF and placed on nutrient agar-plates after drying to remove the solvent. The inhibition zones were measured after $24 \mathrm{~h}$. DMF was used as control and gentamicin as the standard drug.

\subsection{Fungicidal screening}

Antifungal activities of the ligand and the soluble complexes were evaluated by the spore germination technique ${ }^{14}$. Solutions of the test compounds were prepared in DMF $\left(0.5 \mathrm{mg} \mathrm{cm}^{-3}\right)$ and placed on the fungus slide. The slides were incubated for $24-72 \mathrm{~h}$ at $37^{\circ} \mathrm{C}$. A contaminant in the solution indicates $100 \%$ growth of fungus which is represented as,$+ 50 \%$ growth by ++ , less than $50 \%$ growth by +++ , and excellent inhibition by ++++ (see table 7 below in $§ 6.8)$.

\section{Antitumour screening}

\subsection{In vitro DNA synthesis inhibition assay}

Jurket and Daltons lymphoma cell suspensions were prepared in a complete medium (RPMI 1640 medium supplemented with penicillin, streptomycin and $10 \%$ heatinactivated foetal calf serum) at concentrations of $10^{6}$ cells cm${ }^{-3}$ following the literature method ${ }^{15} .2 \times 10^{5}$ cells well $^{-1}$ was added to duplicate wells of a 96-well culture plate (Nunc, Denmark). The cells were treated with test compounds at $10 \mu \mathrm{g} \mathrm{cm}^{-3}$ dose and incubated for $24 \mathrm{~h}$ at $37^{\circ} \mathrm{C}$ in a $\mathrm{CO}_{2}$ incubator. In control sets no treatment was given. After $24 \mathrm{~h}$ of incubation, the cells were washed thrice with RPMI 1640 culture medium (without serum) by centrifugation $(400 \mathrm{~g}$ for $10 \mathrm{~min}$ ). The cell pellets were resuspended in $0.2 \mathrm{~cm}^{-3}$ complete medium containing $1 \mu \mathrm{ci} \mathrm{cm}^{-3}{ }^{3} \mathrm{H}$-thymidine and pulse-labelled for $4 \mathrm{~h}$. The cells were then washed thrice with phosphate buffer saline (PBS), lysed with $1 \%$ sodium dodecyl sulphate (SDS) and the lysate was subjected to radioactivity count in a LKB- $\beta /$-liquid scintillation counter. The percentage inhibition of incorporation was calculated as follows.

$\%$ inhibition $=1-(\mathrm{CPM}$ in treated tumour cells $/ \mathrm{CPM}$ in untreated tumour cells) $\times 100$,

where $\mathrm{CPM}=$ counts per minute.

\subsection{In vitro growth inhibitory assay}

An MTT assay was used to measure the cytotoxic effect of the ligand and its complexes. The pale-yellow tetrazolium salt, [3-(4,5-dimethylthiazol)-2-yl]-2,5- 
diphenyl-2H-tetrazolium bromide] (MTT), was cleaved by active mitochondria to form a dark blue formazan product that can be completely solubilized in acidfied isopropanol and detected by a microtitre plate reader ${ }^{16}$. The assay provides a simple way to detect living and growing cells without using radioactivity. Briefly, $5 \times 10^{4}$ tumour cells (Jurket and Dalton lymphoma) were plated in triplicate in 96-well flat bottom tissue culture plates, and treated with different concentrations of drugs for the time indicated. MTT $\left(0.005 \mathrm{~g} \mathrm{~cm}^{-3}\right.$ in PBS $)$ was added to the cell culture and incubated for $4 \mathrm{~h}$ at $37^{\circ} \mathrm{C}$ in a $5 \%-\mathrm{CO}_{2}$ humidified incubator. The formazan crystals formed during the reaction of active mitochondria with MTT were dissolved in $0.04 \mathrm{~N} \mathrm{HCl}$ $\left(100 \mathrm{~cm}^{3}\right)$ in isopropanol and readings were taken in a microtitre plate reader using a $570 \mathrm{~nm}$ filter. The average drug concentration $\left(\mu \mathrm{g} \mathrm{cm}^{-3}\right)$ for $50 \%$ inhibition $\left(I D_{50}\right)$ of tumour cell-growth was determined by plotting the log of drug concentration vs. the growth rate of tumour cells in the presence of solvent (\% control).

\subsection{Morphological evaluation of apoptotic cells}

A drop of cell suspension was air dried, fixed in $\mathrm{MeOH}$ and stained with Wright's solution (Accustain Wright stain (modified), Sigma), mounted in a permanent medium and analysed under a light microscope (Leitz Wetzlar, Germany) at $100 \times$ magnification. Apoptotic cells were identified on the basis of morphological features that included contracted cell bodies, condensed, uniformly circumscribed and densely stained chromatin or membrane-bound apoptotic bodies containing one or more nuclear fragments ${ }^{17}$. The percent of apoptotic cells was determined by counting more than 300 cells for at least three different determinations.

\subsection{Percent DNA fragmentation assay}

Quantitative determination of DNA fragmentation was carried out following Sellins and Cohen ${ }^{18}$ with slight modifications. Thymocytes $\left(1 \times 10^{6}\right.$ cells cm$\left.{ }^{-3}\right)$ were lysed in

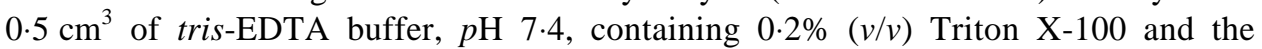
fragmented DNA was separated from intact chromatin in a microfuge tube (labelled as B) by centrifugation at $13,000 \mathrm{~g}$ at $4^{\circ} \mathrm{C}$ for $10 \mathrm{~min}$. Supernatant containing the fragmented DNA was transferred to another microfuge tube (labelled as T). A volume of $0.5 \mathrm{~cm}^{3}$ of $25 \% \mathrm{Cl}_{3} \mathrm{CCO}_{2} \mathrm{H}$ (TCA) was added to each $\mathrm{T}$ and $\mathrm{B}$ tube and vortexed vigorously. DNA was precipitated overnight at $4^{\circ} \mathrm{C}$ and collected by centrifugation at $13,000 \mathrm{~g}$ and then $80 \mu \mathrm{l}$ of $5 \%$ TCA was added to each pellet. DNA was hydrolyzed by heating at $90^{\circ} \mathrm{C}$ for $15 \mathrm{~min}$. At this stage a blank was included containing $80 \mu \mathrm{l}$ of $5 \%$ TCA. Finally, $160 \mu \mathrm{l}$ of freshly prepared DPA reagent $(150 \mathrm{mg}$ diphenylamine in $10 \mathrm{~cm}^{3}$ glacial $\mathrm{AcOH}, 150 \mu \mathrm{l}$ conc. $\mathrm{H}_{2} \mathrm{SO}_{4}$ and $50 \mu \mathrm{l}$ of $\mathrm{MeCHO}$ solution) was added and the tubes were allowed to stand overnight at room temperature to develop colour. $100 \mu \mathrm{l}$ of this coloured solution was transferred to the wells of a 96-well flat-bottomed Elisa plate and the optical density measured at $600 \mathrm{~nm}$ in a microtitre plate reader. The percent DNA fragmentation was calculated as,

$$
\text { percent DNA fragmentation }=[T /(T+B)] \times 100,
$$

where, $T=$ absorbance of fragmented DNA, $T+B=$ absorbance of total DNA. 


\section{Results and discussion}

All the solid complexes are stable in air. The metal thiocyanate complexes are soluble in DMF and DMSO, but insoluble in other organic solvents, while the metal chloride complexes are also soluble in ethanol, methanol and acetone. The molar conductivity of $\left[\mathrm{Ni}(\mathrm{DBtsc}-\mathrm{H})(\mathrm{SCN})\left(\mathrm{H}_{2} \mathrm{O}\right]\right.$ in $10^{-3} \mathrm{M}$ DMF was found to be $73.4 \Omega^{-1} \mathrm{~cm}^{2} \mathrm{~mol}^{-1}$ which falls in the range reported for an 1:1 electrolyte ${ }^{19}$, indicating solvolysis in DMF, while other complexes show molar conductivities of $33.3-63.4 \Omega^{-1} \mathrm{~cm}^{2} \mathrm{~mol}^{-1}$, suggesting their non-electrolytic nature ${ }^{19}$. The following equations represent the formation of the ligand and the complexes.

$$
\begin{aligned}
& \mathrm{PhCONCS}+\mathrm{PhCONHNH}_{2} \rightarrow \mathrm{PhCONHCSNHNHCOPh},^{2} \\
& \text { (DBtsc) } \\
& \mathrm{Mn}(\mathrm{SCN})_{2}+\mathrm{DBtsc} \underset{\mathrm{Stir}}{\stackrel{\mathrm{EtOH}}{\longrightarrow}}[\mathrm{Mn}(\mathrm{DBtsc}-\mathrm{H})(\mathrm{SCN}]+\mathrm{HSCN}, \\
& \mathrm{M}(\mathrm{SCN})_{2}+\mathrm{DBtsc} \underset{\mathrm{Reflux}}{\stackrel{\mathrm{EtOH}}{\longrightarrow}}[\mathrm{M}(\mathrm{DBtsc}-\mathrm{H})(\mathrm{SCN})]+\mathrm{HSCN}, \\
& (\mathrm{M}=\mathrm{Co}(\mathrm{II}) \text { or } \mathrm{Zn}(\mathrm{II})) \\
& \mathrm{Ni}(\mathrm{SCN})_{2}+\text { DBtsc } \underset{\text { Reflux }}{\stackrel{\text { EtOH }}{\longrightarrow}}\left[\mathrm{Ni}(\text { DBtsc-H })(\mathrm{SCN})\left(\mathrm{H}_{2} \mathrm{O}\right)\right]+\mathrm{HSCN}, \\
& \mathrm{Cu}(\mathrm{SCN})_{2}+\mathrm{DBtsc} \underset{\text { Stir }}{\stackrel{\text { DMF }}{\longrightarrow}}\left[\mathrm{Cu}(\text { DBtsc-H })(\mathrm{SCN})\left(\mathrm{H}_{2} \mathrm{O}\right)\right]+\mathrm{HSCN}, \\
& \mathrm{MnCl}_{2} \cdot 4 \mathrm{H}_{2} \mathrm{O}+\mathrm{DBtsc} \underset{\text { Reflux }}{\stackrel{\text { EtOH }}{\longrightarrow}}\left[\mathrm{M}(\mathrm{DBtsc}) \mathrm{Cl}_{2}\right]+4 \mathrm{H}_{2} \mathrm{O}, \\
& \mathrm{NiCl}_{2} \cdot 6 \mathrm{H}_{2} \mathrm{O}+\text { DBtsc } \underset{\text { Reflux }}{\stackrel{\text { EtoH }}{\longrightarrow}}[\mathrm{Ni}(\text { DBtsc-H }) \mathrm{Cl}]+\mathrm{HCl}+6 \mathrm{H}_{2} \mathrm{O}, \\
& \mathrm{CoCl}_{2} \cdot 6 \mathrm{H}_{2} \mathrm{O}+\mathrm{DBtsc} \underset{\text { Stir }}{\stackrel{\text { EtOH }}{\longrightarrow}}[\mathrm{Co}(\text { DBtsc- }-\mathrm{H}) \mathrm{Cl}]+\mathrm{HCl}+6 \mathrm{H}_{2} \mathrm{O}, \\
& \mathrm{CuCl}_{2} \cdot 2 \mathrm{H}_{2} \mathrm{O}+\text { DBtsc } \underset{\text { Reflux }}{\stackrel{\text { EtOH }}{\longrightarrow}}[\mathrm{Cu}(\text { DBtsc-H }) \mathrm{Cl}]+\mathrm{HCl}+2 \mathrm{H}_{2} \mathrm{O} \text {, } \\
& \mathrm{ZnCl}_{2}+\text { DBtsc } \underset{\text { Reflux }}{\stackrel{\text { EtOH }}{\longrightarrow}}[\mathrm{Zn}(\text { DBtsc-H })]+\mathrm{HCl} .
\end{aligned}
$$

\subsection{Magnetic moments}

The magnetic moment value $(5.8 \mathrm{BM})$ for $[\mathrm{Mn}(\mathrm{DBtsc}-\mathrm{H})(\mathrm{SCN})]$ and $\left[\mathrm{Mn}(\mathrm{DBtsc}) \mathrm{Cl}_{2}\right]$, indicates the presence of five unpaired electrons. $[\mathrm{Co}(\mathrm{DBtsc}-\mathrm{H})(\mathrm{SCN})]$ and $[\mathrm{Co}(\mathrm{DBtsc}-$

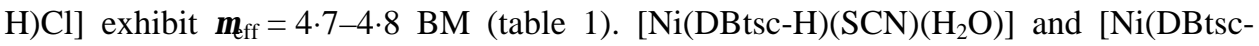
$\mathrm{H}) \mathrm{Cl}$ ] show magnetic moments of 3.3 and $3.2 \mathrm{BM}$ respectively, indicating their tetrahedral geometry. Magnetic moments of $\left[\mathrm{Cu}(\mathrm{DBtsc}-\mathrm{H})(\mathrm{SCN})\left(\mathrm{H}_{2} \mathrm{O}\right)\right]$ and $[\mathrm{Cu}(\mathrm{DBtsc}-$ $\mathrm{H}) \mathrm{Cl}]$ are 1.9 and $1.8 \mathrm{BM}$ respectively, as expected for the presence of one unpaired electron. 


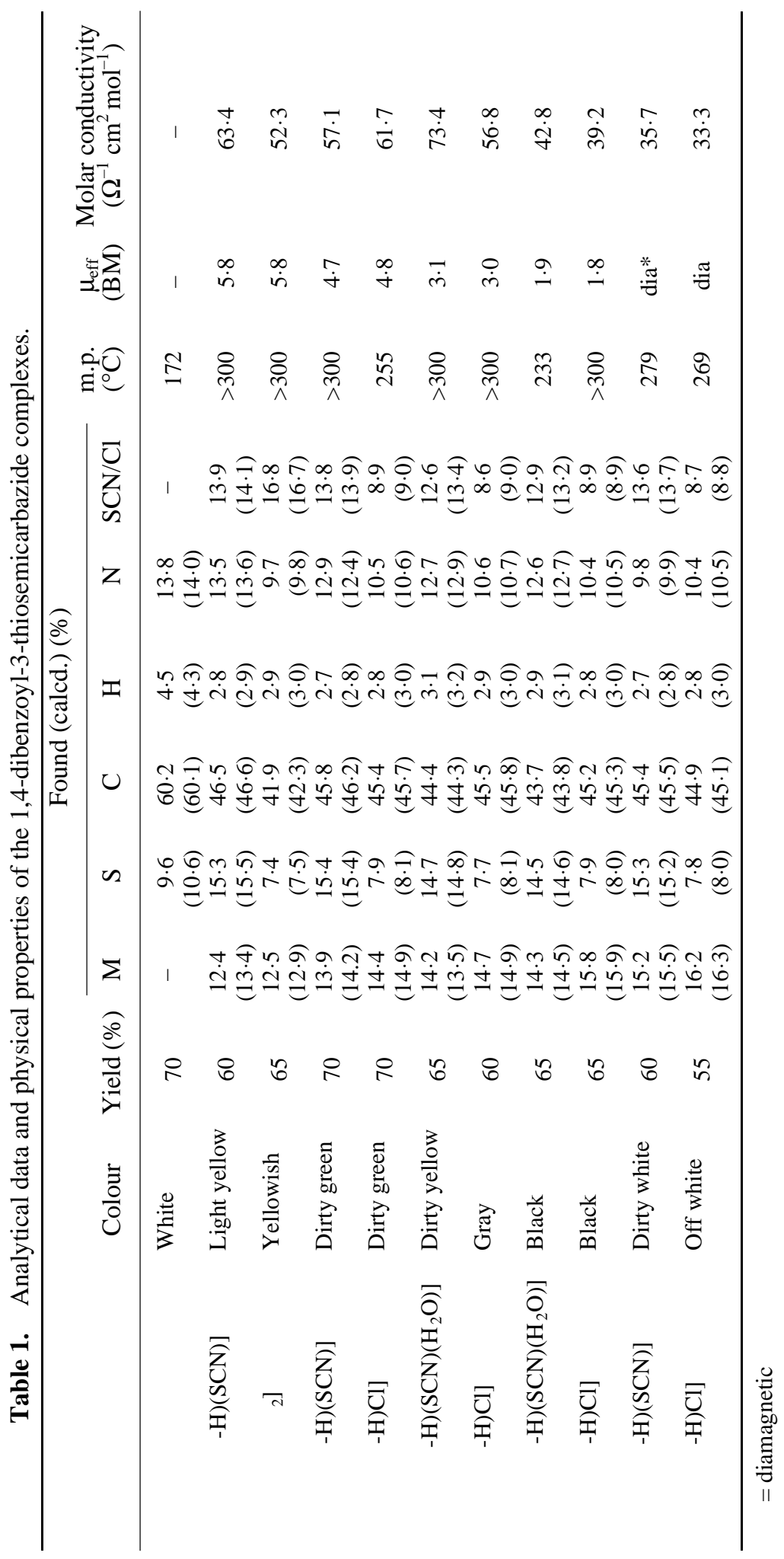




\subsection{Electronic spectra}

In the absence of a $d-d$ band, the value of magnetic moment (5.8 BM) and infrared spectral data suggest tetrahedral arrangement of the ligands around manganese (II). $[\mathrm{Co}(\mathrm{DBtsc}-\mathrm{H})(\mathrm{SCN})]$ shows four bands at 15435, 16615, 17185 and $19015 \mathrm{~cm}^{-1}$ (table 2), while $[\mathrm{Co}(\mathrm{DBtsc}-\mathrm{H}) \mathrm{Cl}]$ exhibits a band at $17360 \mathrm{~cm}^{-1}$ assigned to the ${ }^{4} A_{2} \rightarrow{ }^{4} T_{1}(F)$ $\left(v_{3}\right)$ transition for tetrahedral geometry of $[\mathrm{Co}(\mathrm{DBtsc}-\mathrm{H}) \mathrm{X}][\mathrm{X}=\mathrm{SCN}$ or $\mathrm{Cl}]$. Nickel (II) complexes exhibit two bands at $16025-16665$ and $20205-21185 \mathrm{~cm}^{-1}$, assigned to the ${ }^{3} T_{1}(F) \rightarrow{ }^{3} T_{1}(P)$ and charge transfer $(c t)$ transitions respectively in tetrahedral geometry ${ }^{20}$. [Cu(DBtsc-H)Cl] shows a band at $16130 \mathrm{~cm}^{-1}$ assigned to the envelope of ${ }^{2} B_{1 g} \rightarrow{ }^{2} A_{1 g},{ }^{2} B_{2 g}$ and ${ }^{2} E_{g}$ transitions, while $\left[\mathrm{Cu}(\mathrm{DBtsc}-\mathrm{H})(\mathrm{SCN})\left(\mathrm{H}_{2} \mathrm{O}\right)\right]$ shows two bands at 16995 and $20835 \mathrm{~cm}^{-1}$ due to the envelope of ${ }^{2} B_{1 g} \rightarrow{ }^{2} A_{1 g},{ }^{2} B_{2 g}$ and ${ }^{2} E_{g}$ transitions, and $c t$, suggesting a square-planar structure for the copper (II) complexes ${ }^{20}$.

\subsection{IR spectra}

The IR spectrum of the ligand (table 3) in $\mathrm{KBr}$ shows bands at 3059, 3142 and $3271 \mathrm{~cm}^{-1}$ due to the presence of three $\mathrm{NH}$ groups which are also present in $\left[\mathrm{Mn}(\mathrm{DBtsc}) \mathrm{Cl}_{2}\right]$. The band at $3271 \mathrm{~cm}^{-1}$ is absent in other metal (II) thiocyanato and chloro complexes (table 3 ), indicating loss of a proton via enolisation/thioenolisation in the deprotonated complexes. The peaks at 1633 and $1666 \mathrm{~cm}^{-1}$ are assigned to the $\mathrm{C}=\mathrm{O}$ groups attached to the benzene rings $\mathrm{A}$ and $\mathrm{B}$, respectively. The $v(\mathrm{C}=\mathrm{O})$ band of the ligand at $1666 \mathrm{~cm}^{-1}$ shows a negative shift of $10-42 \mathrm{~cm}^{-1}$ in $[\mathrm{M}(\mathrm{DBtsc}-\mathrm{H})(\mathrm{SCN})]$ $[\mathrm{M}=$ manganese (II), cobalt (II) or zinc (II) $]$ and $[\mathrm{M}(\mathrm{DBtsc}-\mathrm{H}) \mathrm{Cl}][\mathrm{M}=$ cobalt (II), nickel (II), copper (II) or zinc (II)], indicating bonding through the amide oxygen attached to the benzene ring $\mathrm{B}$. The $v(\mathrm{C}=\mathrm{O})$ band of the ligand at $1633 \mathrm{~cm}^{-1}$ is absent in these complexes, but the presence of a new band at $1590-1605 \mathrm{~cm}^{-1}$, due to the $v(\mathrm{~N}=\mathrm{C})$ of NCO, indicates removal of a hydrazinic proton via enolisation, and subsequent participation of the enolic oxygen in bonding. The spectrum of $\left[\mathrm{Mn}(\mathrm{DBtsc}) \mathrm{Cl}_{2}\right]$, however, shows a negative shift of $10 \mathrm{~cm}^{-1}$ in $v(\mathrm{C}=\mathrm{O})$ of the hydrazide part of the ligand, showing bonding through the carbonyl oxygen. The $v(\mathrm{~N}-\mathrm{N})$ ligand band at $999 \mathrm{~cm}^{-1}$ shows a positive shift of $33-83 \mathrm{~cm}^{-1}$ in the complexes, due to bonding through one hydrazinic nitrogen ${ }^{7}$. Thioamide bands $\mathrm{I}[\beta(\mathrm{NH})+v(\mathrm{CN})]$, III $[(v(\mathrm{CN})+$ $\beta(\mathrm{NH})]$ and $\operatorname{IV}[v(\mathrm{C}=\mathrm{S})]$ observed at 1579,1275 and $877 \mathrm{~cm}^{-1}$ respectively in the ligand do not undergo considerable change in the complexes, ruling out the possibility of bonding through the $>\mathrm{C}=\mathrm{S}$ group. In the thiocyanate complexes, $v(\mathrm{C} \equiv \mathrm{N})$ is observed in

Table 2. UV-Visible spectral data of the complexes and their assignments.

\begin{tabular}{lll}
\hline Complex & Band max $\left(\mathrm{cm}^{-1}\right)$ & \multicolumn{1}{c}{ Assignments } \\
\hline$[\mathrm{Co}(\mathrm{DBtsc}-\mathrm{H})(\mathrm{SCN})]$ & $15435,16615,17185$, & \\
& $19015^{*}$ & ${ }^{4} A_{2} \rightarrow{ }^{4} T_{1}(F) v_{3}$ \\
{$[\mathrm{Co}(\mathrm{DBtsc}-\mathrm{H}) \mathrm{Cl}]$} & 17360 & \\
{$\left[\mathrm{Ni}(\mathrm{DBtsc}-\mathrm{H})(\mathrm{SCN})\left(\mathrm{H}_{2} \mathrm{O}\right)\right]$} & $16665,20205^{*}$ & \\
{$[\mathrm{Ni}(\mathrm{DBtsc}-\mathrm{H}) \mathrm{Cl}]$} & $16025,21185^{3}$ & ${ }^{3} T_{1}(F) \rightarrow{ }^{3} T_{1}(P)$ \\
{$\left[\mathrm{Cu}(\mathrm{DBtsc}-\mathrm{H})(\mathrm{SCN})\left(\mathrm{H}_{2} \mathrm{O}\right)\right]$} & $16995,20835^{*}$ & Envelope of ${ }^{2} B_{1 g} \rightarrow{ }^{2} A_{1 g},{ }^{2} B_{2 g}$ and ${ }^{2} E_{g}$, \\
{$[\mathrm{Cu}(\mathrm{DBtsc}-\mathrm{H}) \mathrm{Cl}]$} & 16130 & Envelope of ${ }^{2} B_{1 g} \rightarrow{ }^{2} A_{1 g},{ }^{2} B_{2 g}$ and ${ }^{2} E_{g}$ \\
\hline
\end{tabular}

*charge transfer 


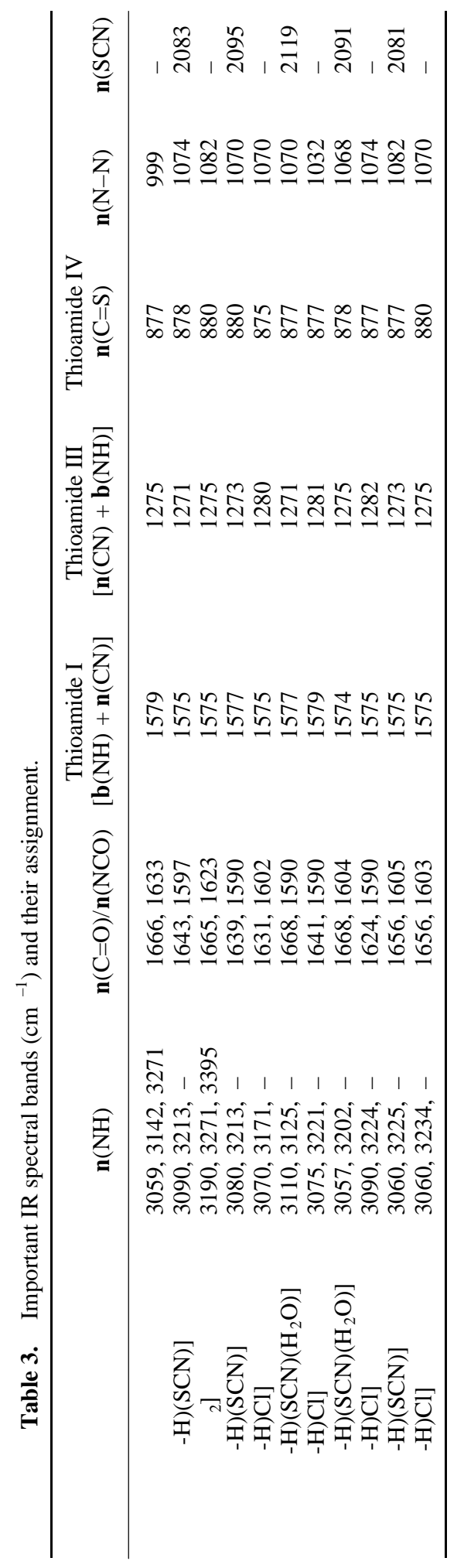


the region of 2081-2119 $\mathrm{cm}^{-1}$, suggesting bonding through the nitrogen of the thiocyanato group ${ }^{21}$. IR spectral data show that the ligand acts as a neutral bidentate in $\left[\mathrm{Mn}(\mathrm{DBtsc}) \mathrm{Cl}_{2}\right]$, mononegative bidentate in $\left[\mathrm{M}(\mathrm{DBtsc}-\mathrm{H})(\mathrm{SCN})\left(\mathrm{H}_{2} \mathrm{O}\right)\right][\mathrm{M}=$ nickel (II) or copper (II)], bonding through the carbonyl/enolic oxygen and the hydrazinic nitrogen. It, however, behaves as a mononegative tridentate in [M(DBtsc-H)(SCN)] $[\mathrm{M}=$ manganese (II), cobalt (II) or zinc (II)] and $[\mathrm{M}(\mathrm{DBtsc}-\mathrm{H}) \mathrm{Cl}][\mathrm{M}=$ cobalt (II), nickel (II), copper (II) or zinc (II)], the bonding sites being the carbonyl as well as enolic oxygens and $\mathrm{N}^{2}$-nitrogen of the ligand (figure 2).

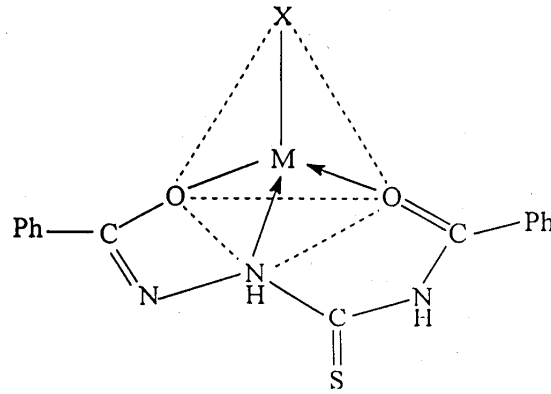

[M(DBtsc-H)X] [M = Mn, Co or Zn], [X = SCN]

$[\mathrm{M}(\mathrm{DBtsc}-\mathrm{H}) \mathrm{X}][\mathrm{M}=\mathrm{Co}, \mathrm{Ni}$ or $\mathrm{Zn}],[\mathrm{X}=\mathrm{Cl}]$

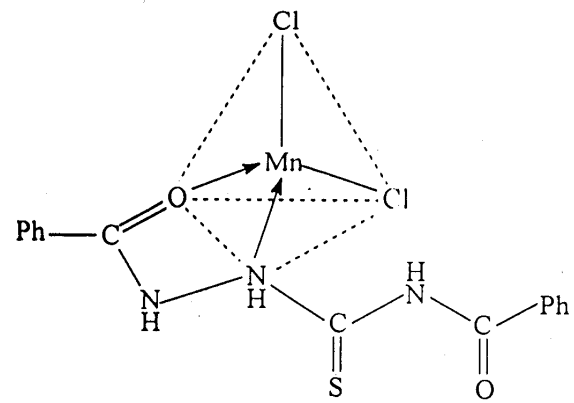

$\left|\mathrm{Mn}(\mathrm{DBtsc}) \mathrm{Cl}_{2}\right|$

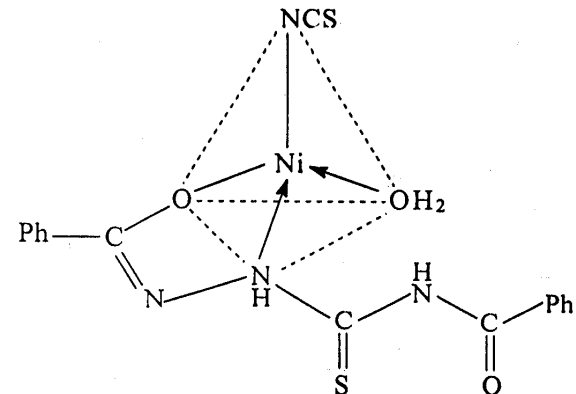

$\left[\mathrm{Ni}(\mathrm{DBtsc}-\mathrm{H})(\mathrm{SCN})\left(\mathrm{H}_{2} \mathrm{O}\right)\right]$

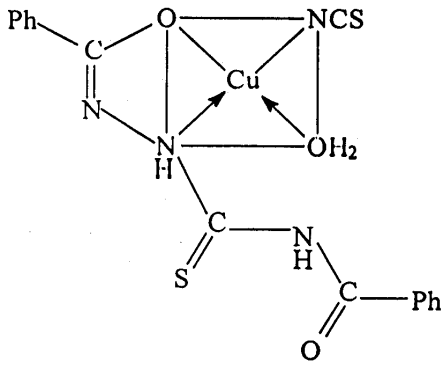

$\left[\mathrm{Cu}(\mathrm{DBtsC}-\mathrm{H})(\mathrm{SCN})\left(\mathrm{H}_{2} \mathrm{O}\right)\right]$

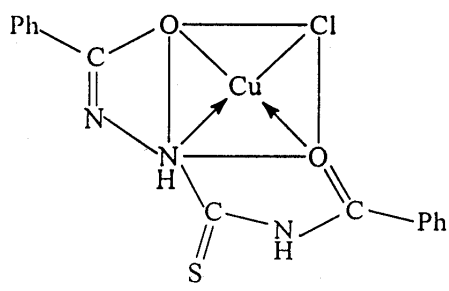

$[(\mathrm{C})(\mathrm{I})[3 \operatorname{tsc}-\mathrm{H})(\mathrm{I})]$

Figure 2. Proposed structure of the complexes. 


\section{$6.4 \quad$ NMR spectra}

The ${ }^{1} \mathrm{H}$-NMR spectrum of the ligand (DBtsc) shows three signals at $\delta 10 \cdot 83(s, 1 \mathrm{H})$, $11.46(s, 1 \mathrm{H})$ and $12.13(s, 1 \mathrm{H}) \mathrm{ppm}$ due to the presence of three $\mathrm{NH}$ groups. Signals at $\delta 7.73-8.13(m, 10 \mathrm{H}) \mathrm{ppm}$ are assigned to the ring protons (table 4$)$. The ${ }^{13} \mathrm{C}-\mathrm{NMR}$ spectrum of DBtsc (table 5) shows eleven signals due to the presence of fifteen carbon atoms. Two signals at $\delta 167.89$ and $164.64 \mathrm{ppm}$ are due to the presence of carbonyl groups attached to the benzene rings $\mathrm{A}$ and $\mathrm{B}$ respectively. The signal at $\delta 180.62 \mathrm{ppm}$ is assigned to the $\mathrm{C}=\mathrm{S}$ carbons. The chemical shift for the ring carbons are $(\delta, \mathrm{ppm})$ $\mathrm{C}(1), 133 \cdot 22 ; \mathrm{C}(2,6), 127 \cdot 53 ; \mathrm{C}(3,5), 128 \cdot 56 ; \mathrm{C}(4), 131 \cdot 92 ; \mathrm{C}^{\prime}(1), 132 \cdot 62 ; \mathrm{C}^{\prime}(2,6)$, 128.77; $\mathrm{C}^{\prime}(3,5), 127 \cdot 75 ; \mathrm{C}^{\prime}(4), 132 \cdot 13 .{ }^{1} \mathrm{H}-\mathrm{NMR}$ spectra of $[\mathrm{Zn}(\mathrm{DBtsc}-\mathrm{H})(\mathrm{SCN})]$ and $[\mathrm{Zn}(\mathrm{DBtsc}-\mathrm{H}) \mathrm{Cl}]$ show two signals at $\delta 10.53-10.58(s, 1 \mathrm{H})$ and $11.40-11.42(s, 1 \mathrm{H})$ $\mathrm{ppm}$, indicating the presence of two-NH protons and loss of $\mathrm{N}^{1} \mathrm{H}$ proton via enolisation. Signals at 7.60 to $7.90(\mathrm{~m}, 10 \mathrm{H}) \mathrm{ppm}$ are assigned to the ring protons. ${ }^{13} \mathrm{C}$ NMR spectra exhibit signals at 180.61 and $180.65 \mathrm{ppm}$ for the $\mathrm{C}=\mathrm{S}$ carbon, which remain practically unchanged, indicating non-participation of the thione sulphur in bonding. The carbonyl signals show an upfield shift of $0 \cdot 13-0 \cdot 15 \mathrm{ppm}$ in [Zn(DBtsc$\mathrm{H})(\mathrm{SCN})]$ and $[\mathrm{Zn}(\mathrm{DBtsc}-\mathrm{H}) \mathrm{Cl}]$, indicating bonding through the enolic as well as carbonyl oxygen atoms.

\subsection{ESR spectra}

The ESR spectrum of $\left[\mathrm{Cu}(\right.$ DBtsc- $\mathrm{H})(\mathrm{SCN})\left(\mathrm{H}_{2} \mathrm{O}\right]$ at room temperature shows two signals with $g_{\|}=2.08$ and $g_{\perp}=2.05$. [Mn(DBtsc-H)(SCN)] shows one signal, $g_{\mathrm{av}}=2 \cdot 01$. These ESR features indicate square-planar and tetrahedral geometries for the copper (II) and manganese (II) complexes respectively.

Table 4. ${ }^{1} \mathrm{H}-\mathrm{NMR}$ data of DBtsc and the complexes $(\delta, \mathrm{ppm})$.

\begin{tabular}{llll}
\hline Compound & \multicolumn{1}{c}{$\mathrm{NH}$} & $\mathrm{NH}_{2}$ & \multicolumn{1}{c}{ Benzene ring } \\
\hline $\mathrm{BAH}^{\mathrm{a}}$ & $9.86(\mathrm{br}, \mathrm{H})$ & $3.86(s, 2 \mathrm{H})$ & $7.86(t, 2 \mathrm{H}), 7.46(d, 3 \mathrm{H})$ \\
$\mathrm{DBtsc}$ & $12 \cdot 13(s, 1 \mathrm{H}), 11.46(s, 1 \mathrm{H})$, & - & $7.73-8.13(\mathrm{~m}, 10 \mathrm{H})$ \\
& $10 \cdot 83(s, 1 \mathrm{H})$ & & \\
{$[\mathrm{Zn}(\mathrm{DBtsc}-\mathrm{H})(\mathrm{SCN})]$} & $11.40(s, 1 \mathrm{H}), 10.58(s, 1 \mathrm{H})$ & - & $7.60-7.90(\mathrm{~m}, 10 \mathrm{H})$ \\
{$[\mathrm{Zn}(\mathrm{DBtsc}-\mathrm{H}) \mathrm{Cl}]$} & $11.42(s, 1 \mathrm{H}), 10.53(s, 1 \mathrm{H})$ & - & $7.66-7.93(m, 10 \mathrm{H})$ \\
\hline
\end{tabular}

${ }^{a}$ Benzoic acid hydrazide

Table 5. ${ }^{13} \mathrm{C}-\mathrm{NMR}$ spectra data $(\delta$, ppm).

\begin{tabular}{|c|c|c|c|c|c|c|c|}
\hline Compound & $>\mathrm{C}=\mathrm{O}$ & $>\mathrm{C}=\mathrm{S}$ & $\mathrm{C}(1)$ & $\mathrm{C}(2,6) \mathrm{C}(3,5)$ & $\mathrm{C}(4)$ & $C^{\prime}(1)$ & $C^{\prime}(2,6) C^{\prime}(3,5) C^{\prime}(4)$ \\
\hline Benzamide & $168 \cdot 27$ & - & - & - & - & $131 \cdot 32$ & $128.23 \quad 127.58 \quad 134.30$ \\
\hline $\mathrm{BAH}^{\mathrm{a}}$ & $166 \cdot 37$ & - & $133 \cdot 38$ & $127 \cdot 15128 \cdot 56$ & $131 \cdot 37$ & - & - \\
\hline DBtsc & $\begin{array}{l}167 \cdot 89 \\
164 \cdot 64\end{array}$ & $180 \cdot 62$ & $133 \cdot 22$ & $127 \cdot 53128.56$ & $131 \cdot 92$ & $132 \cdot 62$ & $128.77 \quad 127.75 \quad 132 \cdot 13$ \\
\hline $\begin{array}{c}{[\mathrm{Zn}(\mathrm{SBtsc}-\mathrm{H})} \\
(\mathrm{SCN})]\end{array}$ & $\begin{array}{l}167 \cdot 76 \\
164 \cdot 49\end{array}$ & $180 \cdot 61$ & $134 \cdot 79$ & $127 \cdot 42128 \cdot 56$ & $129 \cdot 37$ & $133 \cdot 27$ & 128.77127 .69132 .08 \\
\hline $\begin{array}{l}{[\mathrm{Zn}(\mathrm{SBtsc}-\mathrm{H})} \\
\mathrm{Cl}]\end{array}$ & $\begin{array}{l}167 \cdot 75 \\
164 \cdot 49\end{array}$ & $180 \cdot 65$ & $134 \cdot 79$ & $127 \cdot 47128 \cdot 56$ & $129 \cdot 36$ & $133 \cdot 27$ & $12 \cdot 72 \quad 127 \cdot 65 \quad 132 \cdot 08$ \\
\hline
\end{tabular}




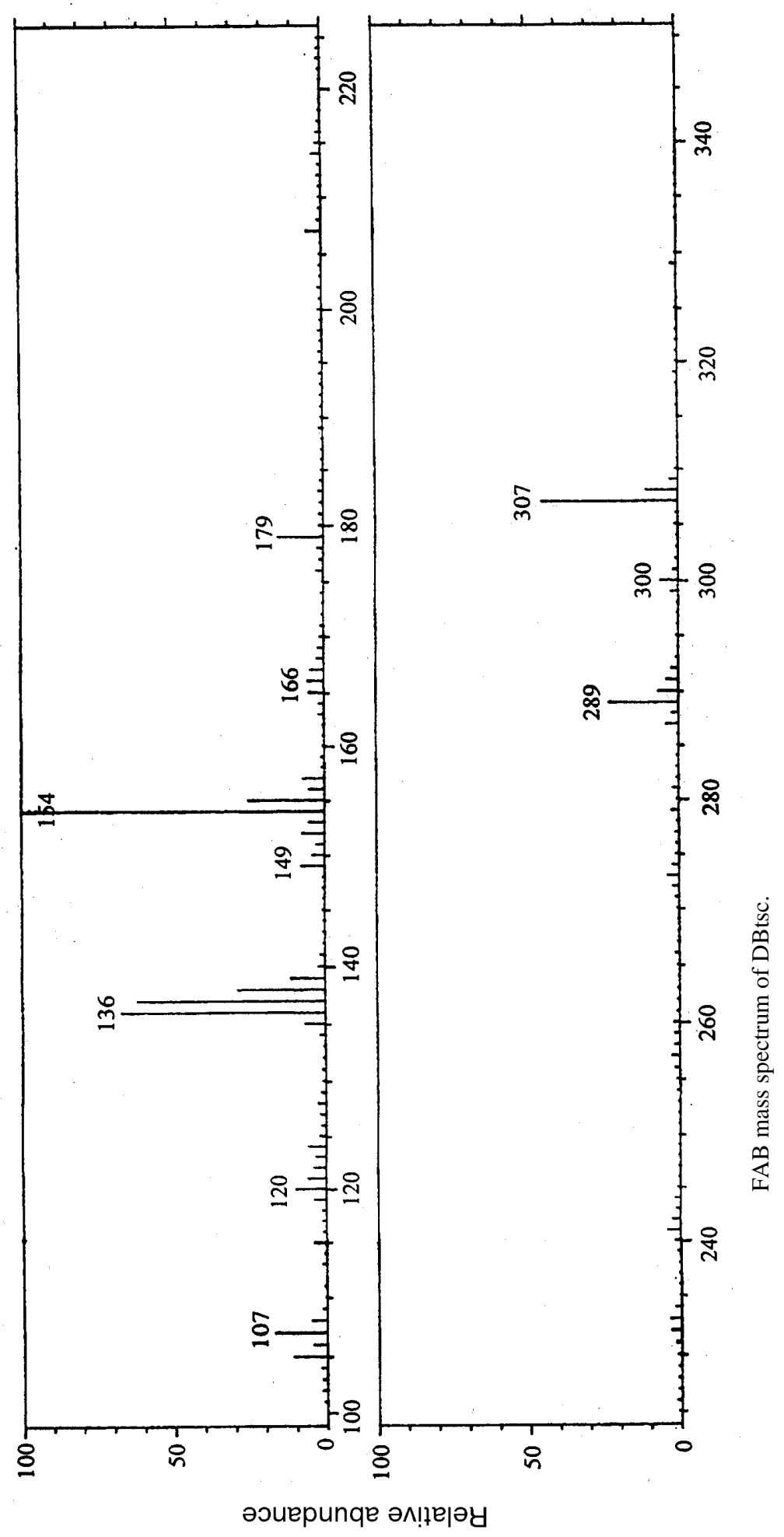




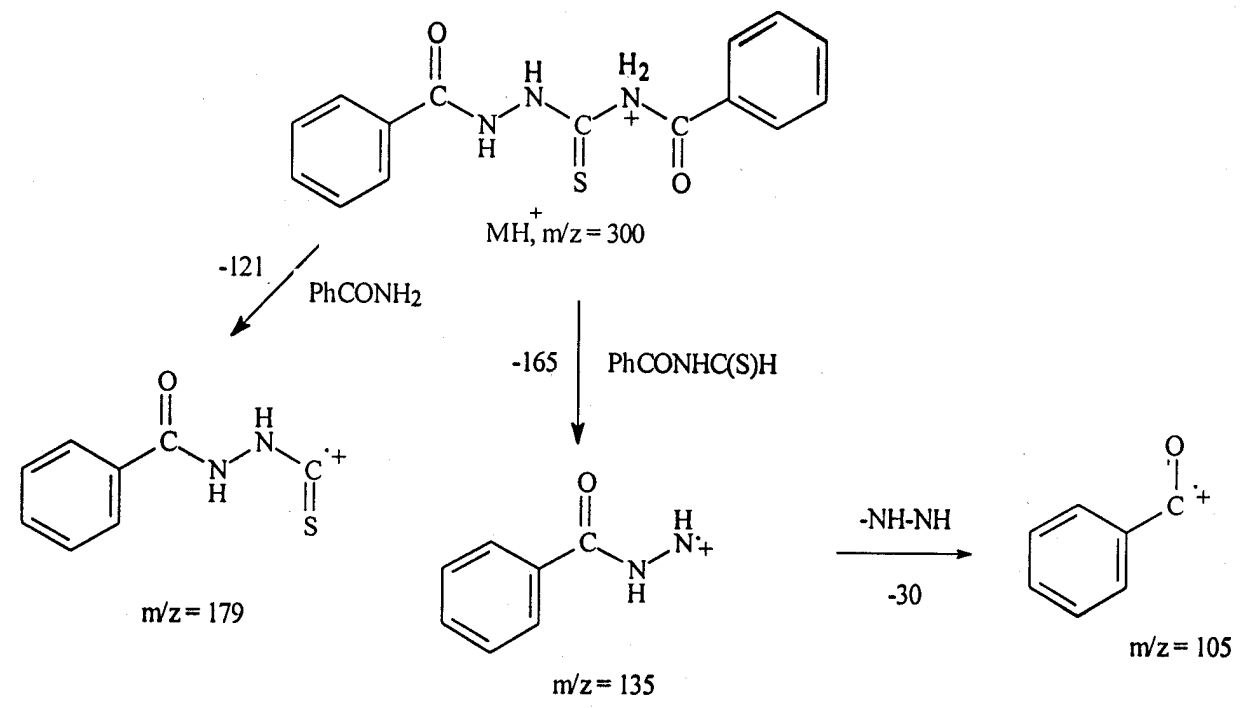

Figure 3b. Fragmentation scheme for DBtsc.

\subsection{FAB mass spectra}

The molecular ion peak $\mathrm{MH}^{+}$for DBtsc is observed at $\mathrm{m} / \mathrm{z}=300$. Other important peaks at 179 and 165 correspond to the release of $\mathrm{PhCONH}_{2}$ and $\mathrm{PhCONHNH}$ from the $\mathrm{MH}^{+}$. The molecular ion peak for $\left[\mathrm{Ni}(\mathrm{DBtsc}-\mathrm{H})(\mathrm{SCN})\left(\mathrm{H}_{2} \mathrm{O}\right)\right]$ is observed at $m / z=433$. The other important peaks at 415, 310, 233 and 175 correspond to the release of $\mathrm{H}_{2} \mathrm{O}$, $\mathrm{PhCO}, \mathrm{Ph}$ and $\mathrm{SCN}$ respectively, from the fragments of $\left[\mathrm{Ni}(\mathrm{DBtsc}-\mathrm{H})(\mathrm{SCN})\left(\mathrm{H}_{2} \mathrm{O}\right)\right]$. Other peaks in the FAB mass spectrum account for the release of SCN, $\mathrm{Ph}$ and $\mathrm{PhCO}$ from the anhydrous complex and its successive fragments. FAB mass spectra of the ligand (DBtsc) and $\left[\mathrm{Ni}(\mathrm{DBtsc}-\mathrm{H})(\mathrm{SCN})\left(\mathrm{H}_{2} \mathrm{O}\right)\right]$ are depicted in figures $3 \mathrm{a}$ and $4 \mathrm{a}$, while the fragmentation schemes are shown in figures $3 \mathrm{~b}$ and $4 \mathrm{~b}$.

\subsection{Bactericidal screening}

Results of antibacterial screening, shown in table 6, indicate that all thicyanato and chloro complexes, inhibit the growth of Pseudomonas flauracences, whereas, the ligand and other complexes are inactive against other seven tested bacteria.

\subsection{Fungicidal screening}

Results of antifungal activity are shown in table 7. The ligand, [M(DBtsc-H)Cl] $[\mathrm{M}=$ cobalt (II) or nickel (II)] and $[\mathrm{Zn}(\mathrm{DBtsc}-\mathrm{H})(\mathrm{SCN})]$ show moderate activity against Aspergillus flavus, while $[\mathrm{M}(\mathrm{DBtsc}-\mathrm{H})(\mathrm{SCN})][\mathrm{M}=$ manganese (II) or cobalt (II)], [Ni(DBtsc-H)(SCN)( $\left.\left.\mathrm{H}_{2} \mathrm{O}\right)\right],\left[\mathrm{Mn}(\mathrm{DBtsc}) \mathrm{Cl}_{2}\right]$ and $[\mathrm{Zn}(\mathrm{DBtsc}-\mathrm{H}) \mathrm{Cl}]$ show good antifungal activity against $A$. flavus. The ligand shows poor activity, while [M(DBtsc$\mathrm{H})(\mathrm{SCN})][\mathrm{M}=$ cobalt $(\mathrm{II})$ or zinc (II) and $[\mathrm{Zn}(\mathrm{DBtsc}-\mathrm{H}) \mathrm{Cl}]$ show moderate activity against Aspergillus niger, $[\mathrm{Mn}(\mathrm{DBtsc}-\mathrm{H})(\mathrm{SCN})], \quad\left[\mathrm{Ni}(\mathrm{DBtsc}-\mathrm{H})(\mathrm{SCN})\left(\mathrm{H}_{2} \mathrm{O}\right)\right]$, $[\mathrm{M}(\mathrm{DBtsc}-\mathrm{H}) \mathrm{Cl}]\left[\mathrm{M}=\right.$ cobalt (II) or nickel (II)] and $\left[\mathrm{Mn}(\mathrm{DBtsc}) \mathrm{Cl}_{2}\right]$ show good 


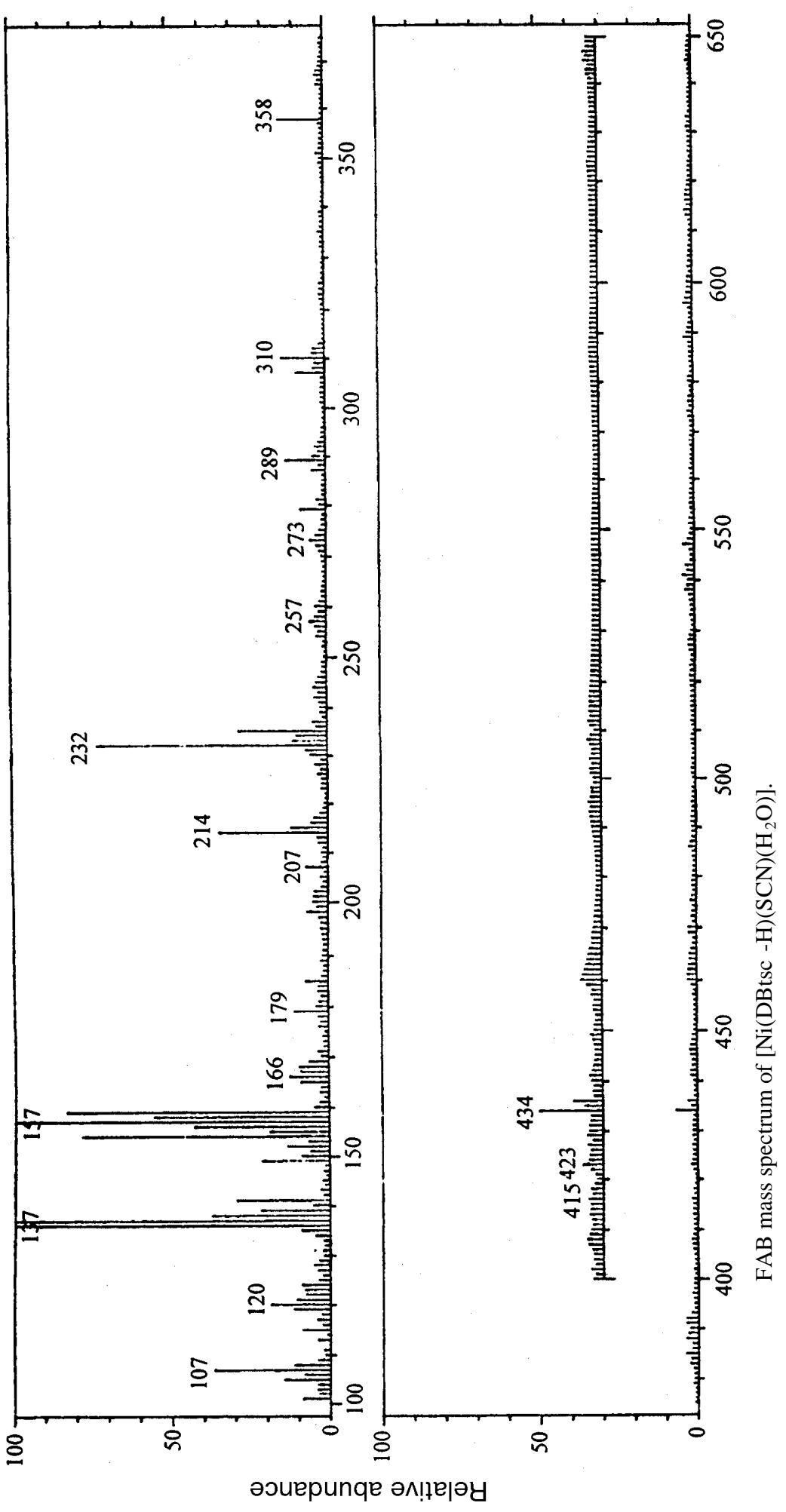


<smiles>O=C(I)NC(=S)N1N=C(c2ccccc2)O[N+]1(O)[As]</smiles>

$\mathrm{m} / \mathrm{z}=433$

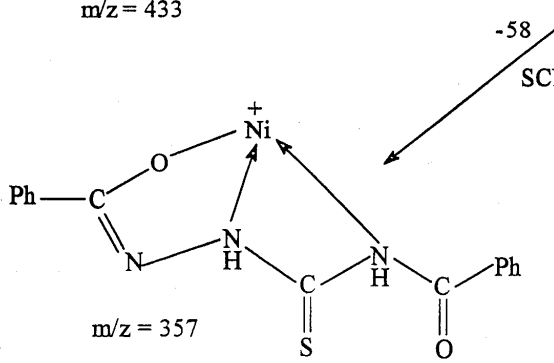<smiles>O=C(NC(=S)N[n+]1ncon1)c1ccccc1</smiles>

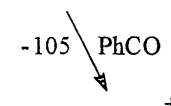<smiles>S=C1N[N+]2NC=C[N+]12</smiles><smiles>CS(=O)(=O)N1NC(=S)N(C(=O)c2ccccc2)O1</smiles>

$\mathrm{m} / \mathrm{z}=415$


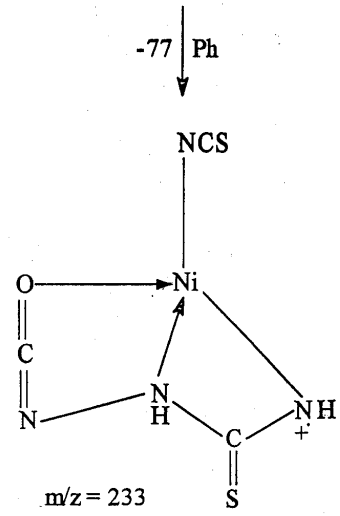

Figure 4b. Fragmentation scheme for $\left[\mathrm{Ni}(\mathrm{DBtsc}-\mathrm{H})(\mathrm{SCN})\left(\mathrm{H}_{2} \mathrm{O}\right)\right]$.

antifungal activity against $A$. niger. $\left[\mathrm{Cu}(\mathrm{DBtsc}-\mathrm{H})(\mathrm{SCN}) \cdot \mathrm{H}_{2} \mathrm{O}\right]$ and $[\mathrm{Cu}(\mathrm{DBtsc}-\mathrm{H}) \mathrm{Cl}]$ exhibit excellent antifungal activity against both the fungi.

\subsection{Antitumour screening}

Results of antitumour screening indicate that the percentage of cell growth in the presence of DBtsc is less than its $\mathrm{Cu}(\mathrm{II})$ thiocyanato/chloro complexes. Percentage 
inhibition of thymidine incorporation data (table 8) show that the ligand has a pronounced inhibitory effect on DNA synthesis, whereas its metal complexes have less inhibitory effect. The ligand showed higher inhibition of thymidine incorporation in Jurket and Daltons lymphoma tumour cells than $\left[\mathrm{Cu}(\mathrm{DBtsc}-\mathrm{H})(\mathrm{SCN})\left(\mathrm{H}_{2} \mathrm{O}\right)\right]$ and $[\mathrm{Cu}(\mathrm{DBtsc}-\mathrm{H}) \mathrm{Cl}]$. Further, the MTT assay performed at $10 \mu \mathrm{g} \mathrm{cm}^{-3}$ corroborated the same finding as is evident from the low $I D_{50}$ values (table 9) for the ligand than those of $\left[\mathrm{Cu}(\mathrm{DBtsc}-\mathrm{H})(\mathrm{SCN})\left(\mathrm{H}_{2} \mathrm{O}\right)\right]$ and $[\mathrm{Cu}(\mathrm{DBtsc}-\mathrm{H}) \mathrm{Cl}]$. To understand the probable mechanism of the antitumour action of these compounds, the mode of cell death was studied and found to be due to apoptosis. The percentages of these apoptotic cells were higher for the ligand than for the complexes. Percentage DNA fragmentation data (table 9) further support the above findings by showing higher values for the ligand

Table 6. Antibacterial activity of DBtsc and its complexes.

\begin{tabular}{lcccccccc}
\hline & \multicolumn{7}{c}{ Bacteria } \\
\cline { 2 - 8 } Compound & a & b & c & d & e & f & g & h \\
\hline DBtsc & - & - & - & - & - & - & - & - \\
{$[\mathrm{Mn}(\mathrm{DBtsc}-\mathrm{H})(\mathrm{SCN})]$} & - & - & - & - & + & - & - & - \\
{$\left[\mathrm{Mn}(\mathrm{DBtsc}) \mathrm{Cl}{ }_{2}\right]$} & - & - & - & - & + & - & - & - \\
{$[\mathrm{Co}(\mathrm{DBtsc}-\mathrm{H})(\mathrm{SCN})]$} & - & - & - & - & + & - & - & - \\
{$[\mathrm{Co}(\mathrm{DBtsc}-\mathrm{H}) \mathrm{Cl}]$} & - & - & - & - & + & - & - & - \\
{$\left[\mathrm{Ni}(\mathrm{DBtsc}-\mathrm{H})(\mathrm{SCN})\left(\mathrm{H}_{2} \mathrm{O}\right)\right]$} & - & - & - & - & + & - & - & - \\
{$[\mathrm{Ni}(\mathrm{DBtsc}-\mathrm{H}) \mathrm{Cl}]$} & - & - & - & - & + & - & - & - \\
{$\left[\mathrm{Cu}(\mathrm{DBtsc}-\mathrm{H})(\mathrm{SCN})\left(\mathrm{H}_{2} \mathrm{O}\right)\right]$} & - & - & - & - & + & - & - & - \\
{$[\mathrm{Cu}(\mathrm{DBtsc}-\mathrm{H}) \mathrm{Cl}]$} & - & - & - & - & + & - & - & - \\
{$[\mathrm{Zn}(\mathrm{DBtsc}-\mathrm{H})(\mathrm{SCN})]$} & - & - & - & - & + & - & - & - \\
{$[\mathrm{Zn}(\mathrm{DBtsc}-\mathrm{H}) \mathrm{Cl}]$} & - & - & - & - & + & - & - & - \\
$\mathrm{Gentamicin}$ & - & - & - & - & + & - & - & - \\
\hline
\end{tabular}

$\mathrm{a}=$ Siglabeoyddi, $\mathrm{b}=$ Citroductree freendii, $\mathrm{c}=$ E. coli, $\mathrm{d}=$ Pseudomonas aeruginosa, $\mathrm{e}=$ Pseudomonas flauracences, $\mathrm{f}=$ Step 25923, $\mathrm{g}=P$. vulgaris, $\mathrm{h}=$ B. subtilis

Table 7. Antifungal activity of DBtsc and its complexes.

\begin{tabular}{lcc}
\hline & \multicolumn{2}{c}{ Inhibition of spore germination $(\%)$} \\
\cline { 2 - 3 } Compound & A. flavus & A. niger \\
\hline DBtsc & ++ & + \\
{$[\mathrm{Mn}(\mathrm{DBtsc}-\mathrm{H})(\mathrm{SCN})]$} & +++ & +++ \\
{$\left[\mathrm{Mn}(\mathrm{DBtsc}) \mathrm{Cl} l_{2}\right]$} & +++ & +++ \\
{$[\mathrm{Co}(\mathrm{DBtsc}-\mathrm{H})(\mathrm{SCN})]$} & +++ & ++ \\
{$[\mathrm{Co}(\mathrm{DBtsc}-\mathrm{H}) \mathrm{Cl}]$} & ++ & +++ \\
{$\left[\mathrm{Ni}(\mathrm{DBtsc}-\mathrm{H})(\mathrm{SCN})\left(\mathrm{H}_{2} \mathrm{O}\right)\right]$} & +++ & +++ \\
{$[\mathrm{Ni}(\mathrm{DBtsc}-\mathrm{H}) \mathrm{Cl}]$} & ++ & +++ \\
{$\left[\mathrm{Cu}(\mathrm{DBtsc}-\mathrm{H})(\mathrm{SCN})\left(\mathrm{H}_{2} \mathrm{O}\right)\right]$} & ++++ & ++++ \\
{$[\mathrm{Cu}(\mathrm{DBtsc}-\mathrm{H}) \mathrm{Cl}]$} & ++++ & ++++ \\
{$[\mathrm{Zn}(\mathrm{DBtsc}-\mathrm{H})(\mathrm{SCN})]$} & ++ & ++ \\
{$[\mathrm{Zn}(\mathrm{DBtsc}-\mathrm{H}) \mathrm{Cl}]$} & +++ & ++ \\
\hline
\end{tabular}


Table 8. Cell proliferation assay and percentage inhibition of thymidine incorporation.

\begin{tabular}{lccc}
\hline & & \multicolumn{2}{c}{ Thymidine incorporation (\%) } \\
\cline { 3 - 4 } Compound & Cell growth (\%) & Jurket & DL* \\
\hline Tumour cell & 100 & - & - \\
DBtsc & $24 \cdot 90$ & $74 \cdot 75$ & $73 \cdot 28$ \\
{$\left[\mathrm{Cu}(\mathrm{DBtsc}-\mathrm{H})(\mathrm{SCN})\left(\mathrm{H}_{2} \mathrm{O}\right)\right]$} & $51 \cdot 32$ & $47 \cdot 19$ & $48 \cdot 72$ \\
{$[\mathrm{Cu}(\mathrm{DBtsc}-\mathrm{H}) \mathrm{Cl}]$} & $52 \cdot 69$ & $45 \cdot 68$ & $47 \cdot 84$ \\
\hline
\end{tabular}

*Dalton's lymphoma

Table 9. In vitro $I D_{50}$, percentage apoptosis and percentage DNA fragmentation for DBtsc and its metal complexes.

\begin{tabular}{|c|c|c|c|c|c|c|}
\hline \multirow[b]{2}{*}{ Compound } & \multicolumn{2}{|c|}{$I D_{50}$ values } & \multicolumn{2}{|c|}{$\%$ Apoptosis } & \multicolumn{2}{|c|}{$\%$ DNA fragmentation } \\
\hline & Jurket & $\mathrm{DL}^{*}$ & Jurket & DL & Jurket & DL \\
\hline Tumour cell & - & - & $36 \cdot 52$ & $35 \cdot 35$ & $39 \cdot 21$ & $40 \cdot 43$ \\
\hline DBtsc & $1 \cdot 2$ & $1 \cdot 3$ & 88.62 & $86 \cdot 42$ & $90 \cdot 20$ & $84 \cdot 73$ \\
\hline$\left[\mathrm{Cu}(\mathrm{DBtsc}-\mathrm{H})(\mathrm{SCN})\left(\mathrm{H}_{2} \mathrm{O}\right)\right]$ & $3 \cdot 7$ & $3 \cdot 2$ & $41 \cdot 21$ & 43.92 & 43.92 & $47 \cdot 53$ \\
\hline$[\mathrm{Cu}(\mathrm{DBtsc}-\mathrm{H}) \mathrm{Cl}]$ & $3 \cdot 8$ & $3 \cdot 7$ & $40 \cdot 10$ & 42.62 & $41 \cdot 23$ & $43 \cdot 82$ \\
\hline
\end{tabular}

$I D_{50}=$ inhibitory dose $\left(\mu \mathrm{g} \mathrm{cm}^{-3}\right)$ for $50 \%$ tumour regression; $* \mathrm{DL}=$ Dalton's lymphoma

than for $\left[\mathrm{Cu}(\mathrm{DBtsc}-\mathrm{H})(\mathrm{SCN})\left(\mathrm{H}_{2} \mathrm{O}\right)\right]$ and $[\mathrm{Cu}(\mathrm{DBtsc}-\mathrm{H}) \mathrm{Cl}]$. Therefore, the ligand possesses higher antitumour activity as compared to its metal complexes. The above finding is in accord with the in vivo antitumour activity of $\mathrm{N}$-salicyloyl- $\mathrm{N}^{\prime}-(2-$ furanthiocarbonyl) hydrazine which is reported to be better than its copper (II) complexes ${ }^{22}$. Results show that the growth inhibition of tumour cells is due to apoptosis in the case of the ligand, whereas the antitumour activity of the copper (II) complexes is not due to apoptosis. It appears that the metal complexes inhibit cellular growth by binding with DNA ${ }^{22}$.

\section{Conclusions}

The ligand DBtsc has been found to bind as neutral bidentate in $\left[\mathrm{Mn}(\mathrm{DBtsc}) \mathrm{Cl}_{2}\right]$, as mono negative bidentate in $\left[\mathrm{M}(\mathrm{DBtsc}-\mathrm{H})(\mathrm{SCN})\left(\mathrm{H}_{2} \mathrm{O}\right)\right][\mathrm{M}=$ nickel (II) or copper (II)], and as mononegative tridentate in $[\mathrm{M}(\mathrm{DBtsc}-\mathrm{H})(\mathrm{SCN})][\mathrm{M}=$ manganese (II), cobalt (II) or zinc (II)] and [M(DBtsc-H)Cl] [M = cobalt (II), nickel (II), copper (II) or zinc (II)]. The ligand exhibits better antitumour activity than $\mathrm{Cu}$ (II) thiocynato/chloro complexes against Jurket and Daltons lymphoma cell lines.

\section{Acknowledgements}

We thank Dr G Nath, Institute of Medical Sciences, BHU for bactericidal screening. Thanks are also due to Dr N K Dubey and Mr Rajesh Kumar Dubey, Department of Botany, BHU for fungicidal screening. 


\section{References}

1. Buu-Hoi N P, Loc T B and Xuong N D 1955 Bull. Soc. Chim. Fr. 694

2. Ali M A and Livingston S E 1974 Coord. Chem. Rev. 13101

3. Petering H G, Buskik H H and Underwood G E 1964 Cancer Res. 64367

4. El-Asmy A A 1989 Bull. Soc. Chim. Fr. 171

5. El-Asmy A A 1988 J. Chin. Chem. Soc. 3529

6. Mostafa M M, Shallaby A M and El-Asmy A A 1981 Transition Met. Chem. 6303

7. El-Asmy A A, Al-Ansi T Y, Amin R R and Mourin M 1990 Polyhedron 92029

8. Aggarwal R C and Yadav R B S 1976 Transition Met. Chem. 1 139; Aggarwal R C and Yadav R B S 1975 Indian J. Chem. A13 727

9. Amberlang J C and Johnson T S 1939 J. Am. Chem. Soc. 61632

10. Curtius T 1894 J. Prakt. Chem. 52278

11. Nakai R, Sugai M and Nakao H 1957 Phasm. Bull. (Tokyo) 5576

12. Vogel A I 1969 A text book of quantitative inorganic analysis 3rd edn (London: ELBS, Longman)

13. Verma R S and Imam S A 1973 Indian J. Microbiol. 1345

14. Adisa V A 1985 Indian Phytopath. 38277

15. Sodhi A and Singh S M 1986 Int. J. Immunopharmacol. 8701

16. Mosamann T R, Cherwinski H, Bond M V, Giedliv M A and Coffmann R 1986 J. Immunol. 132348

17. Kerr J F R, Wyllie A H and Currie A R 1972 Br. J. Cancer 26239

18. Selline K S and Cohen J J 1987 J. Immunol. 1393199

19. Geary W J 1971 Coord. Chem. Rev. 781

20. Lever A B P 1984 Inorganic electronic spectroscopy 2nd edn (Amsterdam: Elsevier)

21. Nathan L C 1974 J. Chem. Educ. 51285

22. Agrawal S, Singh N K, Aggarwal R C, Sodhi A and Tandon P 1986 J. Med. Chem. 29199 